\title{
TOWARDS THE EQUALITY OF PEOPLE WITH DISABILITIES IN THE HEALTH SYSTEM: THE PREPAREDNESS OF HEALTH WORKERS TO WORK WITH PEOPLE WITH HEARING, VISUAL, MOVEMENT AND MENTAL DISABILITIES
}

\author{
Liudmila Rupšienè, Milda Ratkevičienė, Regina Saveljeva \\ Klaipedda University, Lithuania
}

\begin{abstract}
Even though the recent decades have witnessed extensive attempts around the world to ensure the equality of people with disabilities in the health system, it has not been achieved yet. To some extent, the problem is related to the education of health workers to work with people with disabilities. In order to gain more understanding in this regard, this paper focuses on the preparedness of health workers to work with people with hearing, visual, movement and mental disabilities: Is there a link between the studies of the health care workers in higher schools and their preparedness to deal with the specific problems that arise when working with people with hearing, visual, movement and mental disabilities? How does a specific subject / module on working with people with disabilities relate to the preparedness of health workers to address these specific issues? How is it related to the integrated preparation during the study years to work with people with disabilities? A survey of 664 health workers (doctors, nurses, kinesiotherapists, and social workers) working in Lithuania has been conducted. The research revealed that a number of health workers were not properly prepared in higher schools to work with people with hearing, visual, movement and mental disabilities. The research has also revealed that while studying a specific subject / module about working with people with disabilities or studying it in an integrated way across a variety of study activities, health professionals become better prepared to deal with the specific problems of working with people with hearing, visual, movement and mental disabilities. The results of the study suggest the necessity to pay more attention to the particularity of working with people with disabilities in health workers education, so that they are more prepared to work with people with hearing, visual, movement and mental disabilities and ensure more equality and non-discrimination in the healthcare system.
\end{abstract}

Keywords: Health worker education, preparedness to work with people with disabilities, hearing disability, visual disability, movement disability, mental disability, people with disabilities, health system. 


\section{Introduction}

Equality is one of the fundamental values of the contemporary society. Global and European strategic documents declare equal rights for every human being to life, freedom, inviolability, citizenship, etc. (e. g., The Universal Declaration of Human Rights, 1948; The United Nations Charter, 1945; The European Convention for the Protection of Human Rights and Fundamental Freedoms, 1950; The European Social Charter, 1996; The Charter of Fundamental Rights of the European Union, 2000).

As regards specifically the equality of people with disabilities, The Universal Declaration of Human Rights (1948) stipulates that no person can be discriminated on the basis of his or her disability. There are constant attempts in the world to establish equality for people with disabilities before the law, i. e. the human rights to the same protection of the law and to the opportunities provided by law, thus ensuring the same rights as other people have and no exposure to discrimination (Monitoring Report of 2018 on the Results of the Social Integration of Persons with Disabilities and the United Nations Convention on the Rights of Persons with Disabilities and its Optional Protocol, 2019). Despite the global and European Union policies in this regard, The Council of Europe Strategy on the Rights of Persons with Disabilities for 2017-2023 Human Rights: A Reality for All (2017) recognizes that the European Union has so far failed to tackle disability discrimination - people with disabilities face multiple forms of discrimination and therefore cannot achieve "full and equal enjoyment of all human rights and fundamental freedoms" (ibid., 50). In order to change this unsatisfactory situation, the goal is to apply the principle of non-discrimination in all priority areas in the European Union by 2023, and thus achieve the equality of people with disabilities and their dignified life (ibid.).

The recent abandonment of a purely medical approach to disability and the establishment of a biopsychosocial approach, on the basis of which disability is perceived as a result of the interaction of environmental factors and personal characteristics, which can manifest itself on three levels due to the impairment of body functions and structure, activity limitation and participation barriers (World Health Organisation, 2012a), the problem of equality of people with disabilities in the health system has received increasingly more attention (Rupšienè, Ratkevičienė, Saveljeva, 2021). People with disabilities make up a large part of the society. According to the statistics, about 15 per cent of the world's population has a disability of one kind or another (World Health Organization, 2015), there are about 80 million people in the European Union (one in six) with disabilities (The Academic Network of European Disability Expert, 2019), it is likely that at one time or another in their lives, the majority of people have 
experienced, are experiencing, or will experience a short-term or long-term disability (World Health Organization, 2011). Taking this into consideration, there is a growing understanding that disability is a human condition and that almost every one of us can temporarily or permanently lose some powers or abilities to perform one function or another at some point in our lives, and will inevitably face increasing challenges in everyday life related to the advancement of old age (Council of Europe, 2017).

However, despite the increased focus on the rights of people with disabilities in the health system, equality and non-discrimination have not been achieved yet. There are attempts made to identify reasons for this in the education of health workers as well. Even though, and as it has already been mentioned before, the purely medical approach to disability is gradually abandoned, the education of health workers is still mostly based on the medical model and ignores the social and legal aspects of participation of people with disabilities in the health system (Ruškus, 2017; Whitehead, Kathard, Lorenzo, 2019; Baranauskiene, 2020). At the same time, there are many research studies suggesting that the focus on the work with people with disabilities during the study process can be linked to a better situation of people with disabilities in the health system. For example, the inclusion of health-focused subjects in the studies of health workers has been found to have a positive effect on student attitudes, making it easier for them to interact with people with disabilities (Tracy \& Iacono, 2008; Miller, 2015; Sarmiento et al., 2016; Ioerger et al., 2019; Kirshblum et al., 2020). It is also revealed that there is a direct link between the knowledge and negative attitudes towards people with disabilities expressed by the health professionals, and that negative health worker attitudes also have a negative effect on the quality and accessibility of health services for people with disabilities (Sabharwal, 2001; Symons, McGuigan, Akl, 2009; Hearn \& Hearn, 2020). As it becomes evident from the aforementioned and other studies, there lies great potential in the preparedness of health professionals to work with people with disabilities, which should be addressed as a scientific problem in order to find ways to ensure equality and banish the discrimination of people with disabilities in the health system.

This article focuses on several issues stemming from the aforementioned scientific and practical problems: Is there a link between the studies of the health workers in higher schools and their preparedness to deal with the specific problems that arise when practically working with people with hearing, visual, movement and mental disabilities? How does a specific subject/module on working with people with disabilities relate to the preparedness of health workers to address these specific issues? How is it related to the integrated preparation to work with people with disabilities? It is hypothesized that those health workers who have learned about 
working with people with disabilities during their higher education are more prepared to deal with the specific problems faced by health workers when working with people with hearing, visual, movement and mental disabilities, and that it is valuable to study a special subject/module related to the work with people with disabilities during the study process or to study it in an integrated way through various study subjects/modules.

The answers to these questions are sought by analyzing the case of Lithuania, which according to the trends of the problem analyzed, is a quite typical case. In Lithuania, as in other European Union countries, the aim is to ensure equality of people with disabilities in all areas of life, including the health care system, in accordance with The Universal Declaration of Human Rights (1948), The United Nations Charter (1945) and The European Convention for the Protection of Human Rights and Fundamental Freedoms (1950), The European Social Charter (1996), The Charter of Fundamental Rights of the European Union (2000) and other strategic documents of the world and of the European Union. However, despite the legal framework and international obligations, there is still a number of problems in Lithuania, as in the rest of the world, ensuring equal opportunities for people with disabilities in the health system. For example, a research study conducted in Lithuania shows that people with disabilities are not guaranteed the freedom of choice in the health system, their will and wishes are ignored, and they are often forced to use paid services that are too expensive for them (Baranauskienè, 2020). There are also a lot of issues with the services provided at the care facilities (Čiapaitè, Vaitkevičienė, 2020), doctors lack communication competencies necessary when communicating with people with disabilities (Baranauskienè, 2020), and employees providing social services in the health system often hurt these patients, violate ethics, behave irresponsibly, tactlessly, are insensitive and rude (Čiapaitè, Vaitkevičienè, 2020).

With regard to the education of health workers in Lithuania, it should be noted that the legislation regulating studies focused on the health services in the health system does not specify the obligation to supplement the studies with knowledge about people with disabilities or this obligation is very minimal and present only in case of certain studies (e. g. in the case of medicine, nursing and rehabilitation studies) (Ratkevičienė, 2020). Nevertheless, in reality, the study process does involve some preparation for work with people with disabilities: $21.2 \%$ of health workers claim that they have studied a special subject/module about working with people with disabilities, $41.4 \%$ indicate that although they have not studied a special subject/module, such education was still integrated through various study subjects/modules, and only 9.9\% noted that they were not prepared to work with people with disabilities throughout the entire study period at all 
(Rupšienė, Ratkevičienè, Saveljeva, 2021). In Lithuania, there are sporadic research studies on the successful cases of health worker education to work with people with disabilities: for example, the potential of drama therapy as a method of education occupational therapists to work with people with complex disabilities (Burneikaitè, Šertvytienè, Stasiulis, 2015); the impact of the communication skills development program on the effectiveness of communication of oncology health workers with oncology patients and how it is related to the quality of cancer treatment (Bulotienè \& Jagelavičiūte, 2016). Nevertheless, these and other studies raise concerns that the education of health workers does not pay enough attention to people with disabilities, thus preventing them from their right to equal access to health care. Therefore, in Lithuania, as in other countries of the European Union and the world, it is important to analyse the education of health workers to work with people with disabilities, and to initiate changes on the basis of such research, ensuring equality for people with disabilities in the health system.

\section{Method}

\section{Sample}

In search of the answers to the research questions, a survey was conducted in 2019, in which 664 health workers from all over Lithuania were selected via convenience sampling: $6.1 \%(N=107)$ doctors, $12.4 \%$ $(N=218)$ nurses, $5.9 \%(N=103)$ kinesiotherapists, and $13.4(N=236)$ social workers. The majority of respondents were women: $69.2 \%(N=74)$ in the group of doctors, $95.9 \%(N=209)$ in the group of nurses, $80.6 \%$ $(N=83)$ in the group of physiotherapists and $94.1 \%$ in the group of social workers $(N=222)$. The average age of the respondents was 42 years ( $\min =20, \max =73$ ), distribution by education: $15.5 \%$ have incomplete university of applied sciences/university education; $32 \%$ have education in the university of applied sciences; $21.5 \%$ have the first cycle university education (bachelor's degree); $28 \%$ have the second cycle university education (master's degree); $2.9 \%$ have the third cycle university degree (doctoral degree).

\section{Instrument}

The evaluation of the organization of studies to prepare future health workers to work with people with disabilities has been established on the basis of answers to three dichotomous questions: 1) respondents studied a special subject / module about working with people with disabilities; 2) learning about working with people with disabilities was integrated into various study subjects / modules; 3 ) the studies did not include any 
information about working with people with disabilities. The preparedness to address the specific problems encountered when working with hearing, vision, movement, and mental disabilities was addressed by answering four questions. The answers of the respondents were evaluated on the 3-point scale: 1 - feel unprepared, 2 - moderately ready, 3 - very ready.

\section{Data analysis}

Data analysis was performed using SPSS.22. Chi square test was carried out to evaluate whether there is a significant association between the preparedness of health worker groups to work with people with disabilities. Standardized residuals (z-score) were used as a post-hoc analysis for Chisquare test. Cramer's V was used to measure the strength of association between the organization of studies and the preparedness of health workers to address specific problems encountered when working with people with disabilities.

\section{Results}

The Chi square test showed that there is a link between the organization of studies in higher education and the readiness of health professionals to deal with specific problems encountered when working with people with hearing, visual, movement and mental disabilities (Table 1).

Table 1. The link between the organization of studies and the preparedness of health professionals to deal with specific problems arising from working with people with disabilities

\begin{tabular}{|c|c|c|c|c|c|c|c|c|c|c|c|c|}
\hline & \multicolumn{12}{|c|}{$\begin{array}{l}\text { Health workers feel prepared to address the specific challenges of working } \\
\text { with people with disabilities }\end{array}$} \\
\hline & \multicolumn{3}{|c|}{ Hearing } & \multicolumn{3}{|c|}{ Visual } & \multicolumn{3}{|c|}{ Mental } & \multicolumn{3}{|c|}{ Movement } \\
\hline & $\chi^{2}$ & $p$ & 5 & $\chi^{2}$ & $p$ & 5 & $\chi^{2}$ & $p$ & 5 & $\chi^{2}$ & $p$ & 5 \\
\hline $1 *$ & 6.045 & 0.049 & 0.115 & 10.638 & 0.005 & 0.163 & 8.863 & 0.012 & 0.131 & 13.665 & 0.001 & 0.157 \\
\hline $2 *$ & 18.958 & 0.000 & 0.203 & 14.566 & 0.001 & 0.190 & 24.943 & 0.001 & 0.220 & 34.650 & 0.000 & 0.250 \\
\hline $3 *$ & 18.614 & 0.000 & 0.201 & 24.307 & 0.000 & 0.246 & 38.847 & 0.000 & 0.274 & 35.065 & 0.000 & 0.251 \\
\hline
\end{tabular}

* 1 - Had a special module / subject in the study process; 2 - Such preparation was integrated in the study process by studying various modules / subjects; 3 - Did not study it during studies; ** In all cases $\mathrm{df}=2$.

This relationship reveals a general tendency that those health workers who studied a special subject/module about working with people with disabilities during their studies or that such module was integrated into other study subjects/modules and activities, a little more often than not, feel more prepared to deal with specific problems they face when working with 
people with hearing, visual, movement and mental disabilities. Cramer's $\mathrm{V}$-factors are low, indicating that this trend is week.

According to the standardised residual (Table 2), there is a difference between the health workers who studied a special subject/module on working with people with disabilities - they were clearly less likely to mention that they were not prepared to deal with the specific problems they currently face when working with people with hearing impairments ( $28.7 \%$ vs. $42.2 \%$ ), visual impairment (20.4\% vs. $37.9 \%$ ), mental disability (16.5\% vs. $30.4 \%$ ) and movement impairment (14\% vs. $30.2 \%)$.

Table 2. A link between the special subject/module studies with readiness to solve specific problems arising when working with people with disabilities

\begin{tabular}{|c|c|c|c|c|c|c|c|c|c|c|c|c|c|}
\hline & & \multicolumn{12}{|c|}{$\begin{array}{l}\text { Healthcare workers feel prepared to address the specific } \\
\text { challenges of working with people with disabilities }\end{array}$} \\
\hline & & \multicolumn{3}{|c|}{ Hearing } & \multicolumn{3}{|c|}{ Visual } & \multicolumn{3}{|c|}{ Mental } & \multicolumn{3}{|c|}{ Movement } \\
\hline & & $1 *$ & $2 *$ & $3^{*}$ & $1 *$ & $2 *$ & $3 *$ & $1 *$ & $2^{*}$ & $3 *$ & $1 *$ & $2^{*}$ & $3 *$ \\
\hline \multirow[t]{2}{*}{ No } & $\%$ & 42.2 & 19.7 & 38.1 & 37.9 & 25.6 & 36.6 & 30.4 & 26.2 & 43.4 & 30.2 & 21.0 & 48.8 \\
\hline & $\begin{array}{l}\text { Standardised } \\
\text { residuals }\end{array}$ & 0.9 & -0.5 & -0.6 & 1.2 & -0.9 & -0.4 & 1.2 & -0.3 & -0.7 & 1.4 & -0.1 & -1.0 \\
\hline \multirow[t]{2}{*}{ Yes } & $\%$ & 28.7 & 24.8 & 46.5 & 20.4 & 37.6 & 41.9 & 16.5 & 29.6 & 53.9 & 14.0 & 21.5 & 64.5 \\
\hline & $\begin{array}{l}\text { Standardised } \\
\text { residuals }\end{array}$ & -1.7 & 0.9 & 1.1 & -2.2 & 1.7 & 0.6 & -2.2 & 0.5 & 1.3 & -2.7 & 0.1 & 1.9 \\
\hline
\end{tabular}

* The answers of respondents indicate how, during their studies, health workers feel ready to solve specific problems when working with people with disabilities:

1 - unprepared, 2 - moderately ready, 3 - very ready.

Table 3. The link between integrated studies on working with people with disabilities and preparedness to deal with the specific problems that arise when working with them

\begin{tabular}{|c|c|c|c|c|c|c|c|c|c|c|c|c|c|}
\hline & & \multicolumn{12}{|c|}{$\begin{array}{l}\text { Health workers feel prepared to address the specific } \\
\text { challenges of working with people with disabilities }\end{array}$} \\
\hline & & \multicolumn{3}{|c|}{ Hearing } & \multicolumn{3}{|c|}{ Visual } & \multicolumn{3}{|c|}{ Mental } & \multicolumn{3}{|c|}{ Movement } \\
\hline & & $1 *$ & $2 *$ & 3* & $1 *$ & $2 *$ & 3* & $1 *$ & $2 *$ & 3* & $1 *$ & $2 *$ & 3* \\
\hline \multirow[t]{2}{*}{ No } & $\%$ & 47 & 20.1 & 32.7 & 41.0 & 28.2 & 30.8 & 35.9 & 25.4 & 38.7 & 35.8 & 21.4 & 42.8 \\
\hline & $\begin{array}{l}\text { Standardised } \\
\text { residuals }\end{array}$ & 2.1 & -0.3 & -1.9 & 1.8 & 0.0 & -1.7 & 2.8 & -0.5 & -1.8 & 3.1 & 0.1 & -2.3 \\
\hline \multirow[t]{2}{*}{ Yes } & $\%$ & 28.1 & 21.9 & 50.0 & 24.6 & 28.6 & 46.9 & 16.6 & 28.8 & 54.6 & 14.9 & 20.7 & 64.5 \\
\hline & $\begin{array}{l}\text { Standardised } \\
\text { residuals }\end{array}$ & -2.5 & 0.3 & 2.2 & -2.1 & 0.1 & 1.9 & -3.1 & 0.5 & 2.0 & -3.6 & -0.1 & 2.6 \\
\hline
\end{tabular}

* The answers of respondents indicate how, during their studies, health workers feel ready to solve specific problems when working with people with disabilities:

1 - unprepared, 2 - moderately ready, 3 - very ready. 
The data presented in Table 3 show how the preparedness to address the specific problems that arise when working with people with disabilities is related to the integration of this topic into the study process. Those health workers who were getting ready to work with people with disabilities studying various subjects/modules mentioned evidently less often that they were not prepared to address the specific problems they face when working with people with hearing impairments $(28.1 \%$ vs. $47 \%)$ visual disability (24.6\% vs. $41 \%$ ), mental disability (16.6\% vs. $35.9 \%$ ), and movement disability (14.9\% vs. $35.8 \%$ ). They also mentioned significantly more often that they have become well prepared to work with people with hearing (50\% vs. $32.7 \%$ ), vision (46.9\% vs. $30.8 \%$ ), mental (54.6\% vs. $38.7 \%$ ), and movement disability (64.5\% vs $42.8 \%$ ).

The data presented in Table 4 shows how the preparedness to address the specific problems of working with people with disabilities is generally related to studies. Those health workers who did not study anything at all about working with people with disabilities during their studies, were significantly more likely to mention that they were not prepared to address the specific problems they face when working with people with the hearing impairment (68.9\% vs. $36.1 \%$ ), visual disability (69.2\% vs. $30 \%)$, mental disability (64.6\% vs. $23.5 \%$ ) and movement disability (57.9\% vs. $23.1 \%$ ). Moreover, they mentioned significantly less often that they have become very prepared to work with people with hearing (17.8\% vs. $42.3 \%)$, vision (15.4\% vs. $40.2 \%)$, mental ( $14.6 \%$ vs. $48.9 \%)$, and movement disability (21.1\% vs $55.8 \%)$.

Table 4. The link between any studies on working with people with disabilities and preparedness to deal with the specific problems that arise when working with people with disabilities

\begin{tabular}{|c|c|c|c|c|c|c|c|c|c|c|c|c|c|}
\hline & \multicolumn{12}{|c|}{$\begin{array}{l}\text { Health workers feel prepared to address the specific } \\
\text { challenges of working with people with disabilities }\end{array}$} \\
\hline & & \multicolumn{3}{|c|}{ Hearing } & \multicolumn{3}{|c|}{ Visual } & \multicolumn{3}{|c|}{ Mental } & \multicolumn{3}{|c|}{ Movement } \\
\hline & & $1 *$ & $2^{*}$ & $3 *$ & $1 *$ & $2^{*}$ & $3 *$ & $1 *$ & $2 *$ & $3^{*}$ & $1 *$ & $2^{*}$ & $3^{*}$ \\
\hline \multirow[t]{2}{*}{ No } & $\%$ & 36.1 & 21.6 & 42.3 & 30.0 & 29.8 & 40.2 & 23.5 & 27.6 & 48.9 & 23.1 & 21.1 & 55.8 \\
\hline & $\begin{array}{l}\text { Standardised } \\
\text { residuals }\end{array}$ & -1.0 & 0.4 & 0.8 & -1.2 & 0.5 & 0.7 & -1.6 & 0.3 & 1.0 & -1.5 & 0.0 & 1.1 \\
\hline \multirow[t]{2}{*}{ Yes } & $\%$ & 68.9 & 13.3 & 17.8 & 69.2 & 15.4 & 15.4 & 64.6 & 20.8 & 14.6 & 57.9 & 21.1 & 21.1 \\
\hline & $\begin{array}{l}\text { Standardised } \\
\text { residuals }\end{array}$ & 3.2 & -1.1 & -2.4 & 3.8 & -1.5 & -2.3 & 4.9 & -0.8 & -3.2 & 4.6 & 0.0 & -3.3 \\
\hline
\end{tabular}

* The answers of respondents indicate how, during their studies, health workers feel ready to solve specific problems when working with people with disabilities:

1 - unprepared, 2 - moderately ready, 3 - very ready. 


\section{Discussion}

The research study has revealed the importance of the preparedness of health workers to work with people with disabilities throughout their study process. This can be indicated by some of the trends identified - they feel more prepared to deal with the specific problems that arise when working with people with hearing, visual, movement and mental disabilities, those health workers who are prepared for work with people with disabilities in some way and form during the study years, had a special study subject/ module or studied it in an integrated way through several study subjects/ modules and other activities. Thus, the hypothesis raised at the beginning of the investigation could not be falsified. At the same time, there is further evidence of the benefits of including a special subject/module on people with disabilities in the study program for people with disabilities in the health system identified by other researchers (e. g., Tracy \& Iacono, 2008; Miller, 2015; Sarmiento et al. 2016; Ioerger et al., 2019; Kirshblum et al., 2020). Taking this into consideration, in order to improve the situation of people with disabilities in the health system and ensure their equal rights, it is appropriate to supplement education programs for health workers with activities that bring focus on the work with people with disabilities.

On the other hand, it is still noteworthy that some health workers who were somehow involved in preparing to work with people with disabilities during their studies feel unprepared to deal with the specific problems that arise when working with people with hearing, visual, movement and mental disabilities. This idea suggests that the very fact that future health workers are trained to work with people with disabilities does not guarantee their proper preparation to work in practice. Other researchers also analyse the problems of the inability to transfer the theoretical knowledge into practice. For example, Kuper and D'Eon (2011) note that despite strong theoretical preparation and available knowledge, a large proportion of nurses, especially those who have started work, are unable to properly apply the available theoretical knowledge in practice, and Teagle et al. (2017) highlight the same problem, sensitive among graduating and beginning physicians, who also have a low ability to apply theoretical knowledge in practice. According to this, it is necessary to further investigate this problem in order to find factors for the future education of health workers to work with people with disabilities that ensure their more effective preparation for work.

In addition, it has become clear that some health workers who have not been specifically prepared to work with people with disabilities during their studies still feel very well prepared to deal with the specific problems of working with people with hearing, visual, movement and mental 
disabilities. This seems rather paradoxical and could be linked to research findings that provide evidence that some health professionals overestimate some of their professional competencies. E. g. Kee et al. (2018) suggest that physicians tend to overestimate their relationships with patients, i. e., health professionals rate their relationships and interactions with patients better than patients do on their side. In general, Cucchetti et al. (2020) has noted that there is a problem of self-overestimation of physicians, which is directly related to the work experience and their age - physicians tend to overestimate themselves and their knowledge in diagnosing diseases and making predictions. Still, it is unclear how health professionals can be prepared to deal with the specific problems that arise when working with people with hearing, visual, movement and mental disabilities if they have not studied this during their studies at all. This ambiguity can be addressed by new research.

The research study, despite considerable efforts, failed to ensure the randomness of the sample, and which is considered to be the main limitation of the study. In further research, it would be worthwhile to purposefully select subpopulations of health workers, to perform random selection in them and to examine in detail the focus of studies on working with people with disabilities.

\section{Conclusion}

Studies in higher education that include the work with people with disabilities into consideration, prepare health workers to work with people with hearing, visual, movement, and mental disabilities better. This in turn leads to a better situation for people with disabilities in the health system, ensuring their equality and non-discrimination on the grounds of disability.

\section{References}

Baranauskienè, I. (2020). Teisés ị sveikatos priežiūra paradoksas [The paradox of the right to health care]. Klaipèdos universiteto leidykla.

Bogdanova, J., Večkienè, N. (2009). Partnerystė rengiant socialinius darbuotojus: tarpdisciplininès komandos patirtis psichiatrijos skyriuje [Partnership in educating social workers: experience of interdisciplinary team in the department of mental health]. Socialinis Darbas. Patirtis ir Metodai [Social Work. Experience and Methods], 3(1), 23-42.

Burneikaitè, S., Šertvytienè, V., Stasiulis, A. (2015). Dramos terapijos metodų taikymas ergoterapijos studiju metu [Drama therapy methods in occupational therapy studies]. Sveikatos mokslai [Health Sciences in Easter Europe], 25(3), 22-25. 10.5200/ sm-hs.2015.044.

Cucchetti, A., Evans, D., Casadei-Gardini, A., Piscaglia, F., Maroni, L., Odaldi, F., Ercolani, G. (2020). The Perceived Ability of Gastroenterologists, Hepatologists and 
Surgeons Can Bias Medical Decision Making. International Journal of Environmental Research and Public Health, 17(3), 1058. https://doi.org/10.3390/ijerph17031058.

Čiapaitė L., Vaitkevičienè A. (2020). How do People with Disabilities Evaluate the Quality of Social Services? Socialine Teorija, Empirija, Politika ir Praktika [Social Theory, Empirics, Police and Practice], 21, 37-65. doi: https://doi.org/10.15388/ STEPP.2020.22.

Charter of Fundamental Rights of the European Union (2000). Retrieved from: https:// eur-lex.europa.eu/legal-content/LT/TXT/HTML/?uri $=$ CELEX:12012P/TXT\&froM=EN.

Europos socialinè chartija [The European Social Charter] (1996). Valstybès Žinios [Official Gazette], 2001-06-08, No. 49-1704.

Council of Europe (2017). Human rights: a reality for all - Council of Europe Disability Strategy 2017-2023. Retrieved from: https://edoc.coe.int/en/people-with-disabilities/7276-pdfhuman-rights-a-reality-for-all-council-of-europe-disability-strategy-2017-2023.html.

Europos žmogaus teisių ir pagrindinių laisvių apsaugos konvencija [Convention for the Protection of Human Rights and Fundamental Freedoms] (1950). Valstybès Žinios [Official Gazette], 1995-05-16, No. 40-987.

Hearn, S. L., Hearn, P. J. (2020). Working With People With Disabilities: An Interactive Video/Lecture Session for First- and Second-Year Medical Students. The AAMC Journal of Teaching and Learning Resources, 16(10913), 1-8. https://doi.org/10.15766/ mep_2374-8265.10913.

Ioerger, M., Flanders, R. M.; French-Lawyer, J. R.; Turk, M. (2019). Interventions to Teach Medical Students About Disability, American Journal of Physical Medicine \& Rehabilitation, 98(7), 577-599. 10.1097/PHM.0000000000001154

Jungtinių tautų chartija [Charter of the United Nations] (1945). Valstybès Žinios [Official Gazette], 2002-02-13, No. 15-557.

Kee, J., Khoo, H., Lim, I., Koh, M. (2018). Communication Skills in Patient-Doctor Interactions: Learning from Patient Complaints. Health Professions Education, 4(2), 97-106. https://doi.org/10.1016/j.hpe.2017.03.006.

Kirshblum, S., Murray, R., Potpally, N., Foye, P. M., Dyson-Hudson, T., DallaPiazza, M. (2020). An introductory educational session improves medical student knowledge and comfort levels in caring for patients with physical disabilities. Disability and Health Journal, 13, 1-6. 10.1016/j.dhjo.2019.100825.

Kuper, A., \& D’Eon, M. (2011). Rethinking the basis of medical knowledge. Medical Education, 45, 36-43.

Lietuvos Respublikos Konstitucija [Constitution of the Republic of Lithuania] (1992). Valstybès Žinios [Official Gazette], 1992, No. 33-1014.

Miller, S. R. (2015). Fostering informed empathy through patient-centred education about persons with disabilities. Perspectives on Medical Education, 4, 196-199. https:// doi.org/10.1007/s40037-015-0197-5.

Neigaliuju socialines integracijos veiklos rezultaty bei jungtiniu tautu neigaliuju teisiu konvencijos ir jos fakultatyvaus protokolo $2018 \mathrm{~m}$. stebesenos ataskaita [Monitoring report on the social integration performance of people with disabilities and United Nations Convention on the rights of persons with disabilities and its optional protocol 2018] (2019). Retrieved from: http://www.ndt.lt/wp-content/uploads/JT_neigaliuju_teisiu_konvencijos_stebesenos_ ataskaita_GALUTINE.pdf. 
Rimdeikienè, S. (2008). Neigalių asmenų teisių reglamentavimas tarptautinëje teisèje teisnumo ir subjektinès teisès kontekste [Regulation of the rights of the disabled by international law within the context of legal capacity and subjective right]. Jaunuju Mokslininku Darbai [Journal of Young Scientists], 4(20), 221-228.

Rupšienè, L., Ratkevičienè, M., Saveljeva, R. (2021). Žmonès su negaliomis sveikatos sistemoje: aktualijos sveikatos darbuotoju edukacijos kontekste [People with disabilities in the health system: Topical issues in the context of health worker education]. Klaipedos universiteto leidykla.

Ruškus, J. (2017). Lygybės ir nediskriminavimo neigaliesiems gali tekti laukti dar šimtą metu, jei... [Equality and non-discrimination for people with disabilities may have to wait another hundred years if ...]. Socialinis Darbas: Patirtis ir Metodai [Social Work. Experience and Methods], 20(2), 117-122.

Sabharwal, S. (2001). Objective assessment and structured teaching of disability etiquette. Academic Medicine, 76(5), 509-509.

Sarmiento, C., Miller, S. R., Chang, E., Zazove, P., Kumagai, A. K. (2016). From impairment to empowerment: A longitudinal medical school curriculum on disabilities. Academic Medicine. Journal of Association of American Medical Colleges, 91(7), 954-957. 10.1097/ACM.0000000000000935.

Symons, A. B., McGuigan, D., Akl, E. A. (2009). A curriculum to teach medical students to care for people with disabilities: development and initial implementation. BMC Medical Education, 9(78), 1-7. 10.1186/1472-6920-9-78.

Teagle, A. R., George, M., Gainsborough, N., Haq, I., Okorie, M. (2017). Preparing medical students for clinical practice: easing the transition. Perspectives on Medical Education, 6, 277-280. https://doi.org/10.1007/s40037-017-0352-2.

The Academic Network of European Disability Expert (ANED) (2019). Report on independent living for disabled people in Europe. Retrieved from: https://www.disabilityeurope.net/downloads/1042-task-year-4-2018-19-policy-theme-il-synthesis-report-2easy-to-read-version.

Tracy, J., Iacono, T. (2008). People with developmental disabilities teaching medical students - Does it make a difference? Journal of Intellectual \& Developmental Disability, 33(4), 345-348. 10.1080/13668250802478633.

Vaičekauskaitė, R. (2021). Negalios studiju kritinis diskursas sveikatos mokslų kontekste [Critical discourse of disability studies in the context of health sciences]. Klaipedos universiteto leidykla.

Visuotinè žmogaus teisių deklaracija [Universal Declaration of Human Rights] (1948). Valstybès Žinios [Official Gazette], 2006-06-17, No. 68-2497.

Whitehead, S., Kathard, H., Lorenzo, T. (2019). Why disability should be included in the professional education of general practice medical doctors. Preprints, 1-14. 10.20944/ preprints201905.0209.v1.

World Health Organization (2011). Rio political declaration on social determinants of health. Rio de Janeiro, Brazil, 21 October 2011 Retrieved from: https://www.who.int/ sdhconference/declaration/Rio_political_declaration.pdf?ua $=$.

World Health Organization (2012). Executive Board 30 November 2012 report EB132/10. Retrieved from: https://apps.who.int/gb/ebwha/pdf_files/EB132/B132_10-en.pdf

World Health Organization (2015). WHOglobal disability action plan 2014-2021. Better health for all people with disability. Retrieved from: https://apps.who.int/iris/bitstream/handle/ 
10665/199544/9789241509619_eng.pdf;jsessionid = DD0055EEC51D278E6A7215891 FBFF5BF? sequence $=1$.

World Health Organization (2016a). Global strategy on human resources for health: workforce 2030. Geneva, Switzerland. Retrieved from: https://apps.who.int/iris/ bitstream/handle/10665/250368/9789241511131-eng.pdf?sequence $=1$.

World Health Organization (2016b). Working for health and growth: investing in the health workforce. Retrieved from: https://apps.who.int/iris/bitstream/handle/10665/250047/ 9789241511308-eng.pdf? sequence $=1$. 